\title{
EFFECT OF MATERNAL PROTEIN DEPRIVATION ON MORPHOLOGICAL AND QUANTITATIVE ASPECTS OF THE MYENTERIC PLEXUS NEURONS OF PROXIMAL COLON IN RATS
}

\author{
EMERI V.S. LFITE-MELUO*, SANDRA REGINA STABILE** MARCÍLO H. MIRANDA-NETO**
}

\begin{abstract}
We have studied the morphological and quantitative aspects of the myenteric plexus neurons of the proximal colon in rats (Rattus norvegicus of Wistar strain) submitted to a protein deprivation during prenatal and lactation periods. Twenty pregnant dams were divided in four groups labeled according to the kind of nourishment they were given: Group NN, normal diet; Group DN, low protein diet during prenatal period, and normal diet during lactation period; Group ND, normal diet during prenatal period, and low protein diet during lactation period; Group DD, low protein diet during prenatal and lactation periods. Histological analyses were developed with proximal colon segments using the haematoxylin and eosin staining method. Membrane preparations were stained by Giemsa's method. The statistical analysis has demonstrated no significant difference among the means of neurons found in the four studied groups. It was noticed that the animals under protein deprivation during prenatal and lactation periods presented greater quantity of large and strongly basophilic myenteric neurons. This suggests that neurons have accumulated protein in the cytoplasm.
\end{abstract}

KEY WORDS: enteric neurons, myenteric plexus, proteic deprivation, proximal colon, gestation, lactation.

Efeito da desnutriçāo protéica materna nos aspectos morfológico e quantitativo dos neurônios do plexo mientérico do colo proximal de ratos

RESUMO - O objetivo deste trabalho foi estudar os aspectos morfologicos e quantitativos dos neurônios do plexo mientérico do colo proximal de ratos Wistar submetidos a desnutrição protéica, durante a gestação e lactação. Foram utilizados vinte animais, denominados de acordo com o período em que suas mães receberam ração com baixo teor de proteína: grupo NN (normoalimentados), grupo DN (ração hipoprotéica na gestação e normal na lactação), grupo ND (ração normal na gestação e hipoprotéica na lactação) e grupo DD (ração hipoprotéica na gestaçāo e lactação). Amostras do colo proximal destinaram-se a cortes histológicos, corados pela hematoxilina-eosina e a preparados de membrana corados pelo método de Giemsa. $O$ tratamento estatístico não demonstrou diferença significativa entre as médias referentes ao número de neurônios encontrados nos diferentes grupos nutricionais. Verificou-se que animais que sofreram deprivação protéica nos perfodos de gestação e lactação apresentaram maior proporção de neurônios mientéricos grandes e fortemente basofílicos, indicando portanto que estes acumularam material protéico em seu citoplasma.

PALAVRAS-CHAVE: colo proximal, desnutrição protéica, neurônios entéricos, plexo mientérico, gestação, lactação.

Reviewing the available data, it was found that many authors direct their studies to the effect of undernutrition on the central nervous system ${ }^{3,16,18,19}$. Few were the studies found relating to the effects of undernutrition on the peripheral nervous system, and fewer were the studies found concerning

Departamento de Ciências Morfofisiológicas da Universidade Estadual de Maringá (UEM): *Professora Auxiliar; **Professor Doutor Adjunto. This paper is part of the Biological Sciences Thesis of the first author. Aceite: 19-outubro-1996.

Dr. Marcílio H. Miranda Neto - Departamento de Ciências Morfofiológicas UEM - Avenida Colombo 5790 87020-900 Maringá PR - Brasil. 
the myenteric plexus neurons (MP) ${ }^{4,14,15,16}$. It was noticed that several researchers paid special attention to the effects of undernutrition during the prenatal and lactation periods, considering they are the critical ones for the cellular development ${ }^{4,714,15,16}$. It was observed that several researchers proceeded the sacrifice of the animals immediately after the malnutrition period, i.e., right after short period of recovery when they were fed a normal protein diet $^{4.7 .16}$. It was also found the extremes when the sacrifice of the animals occurred after very long period of recovery. ${ }^{4}$ Considering that, it was decided to carry out a study with the purpose of analyzing the effect of protein deprivation on the myenteric plexus neurons in rats.

Initially, our research group studied the MP in the duodenum ${ }^{14}$, but as it is known, each segment has its MP formed by different neuronic populations ${ }^{2,8,9,17}$, thus malnutrition may affect this plexus in a specific way in each intestinal segment. For that reason, researches were followed studying the morphological and quantitative aspects of the myenteric plexus neurons of the proximal colon in rats submitted to protein deprivation during prenatal and lactation periods.

\section{MATERIAL AND METHODS}

The present investigation was performed in the proximal colon of 20 laboratory animals, Rattus norvegicus, of Wistar strain, from the Central Vivarium of State University of Maringá. Pregnant dams were isolated in individual cages and labeled according to the kind of nourishment they were given.

NUVILAB rat pellets (recommended by National Research Council \& National Institute of Health, USA) with $22 \%$ of protein content was given to the animals. By adding corn starch, its protein level was reduced to $8 \%$. The protein levels were tested according to semimicro Kjedahl method, and the low protein nourishment was supplemented with B-12 complex vitamins and a mixture of mineral salts.

The animals were fed ad libitum. The groups were named according to the protein content of the nourishment offered to the pregnant dams: NN, normal protein diet $(22 \%)$ during the prenatal and lactation periods; DN, low protein diet $(8 \%)$ during the prenatal period, and normal nourishment $(22 \%)$ during the lactation period; ND, nomal nourishment during prenatal period and of low protein content during lactation; DD, low protein diet during prenatal and lactation periods.

Within 24 hours of birth, neonates exceeding 6 in each litter, as well as those under 6 were discarded.

After weaning (21 days), all pups were given normal nourishment. At 60 days of age, they were sacrificed. Initially the rats were anesthetized through inhalation of sulfuric ether for about three minutes so that they did not react to painful stimulation. Next the laparotomy was carried out, one minute being necessary to remove the intestine and imerse it in Giemsa for the membrane preparings and $10 \%$ formol for the histological sections. The animals were them killed on the room of histological routines between 8:00 and 9:00 AM. Membrane stainings were carried out with the same group of stains. The samples were exposed to the Giemsa staim at 17:00 hs and removed at 10:00 AM the next day.

\section{Morphological and quantitative study of the myenteric plexus of the nervous cells}

Samples of proximal colon of 5 animals of each studied control group were submitted to elaboration of membrane preparations using the Giemsa method, according to Barbosa. ${ }^{1}$ It was avoided collecting samples from the segment that was facing the mesocolic face. Some segments were submitted to a routine histological treatment of Haematoxylin and Eosin Staining to clearly show the ganglia on the intestinal wall.

\section{Quantitative analysis}

To quantify the myenteric plexus neurons a sampling by counting was carried out. Each membrane preparation was divided in four and, inside each one, ten fields of the microscope with $40 \mathrm{X}$ lens were chosen randomly. All neurons of each field were counted, disregarding the half neurons of one field and considering them in the next. ${ }^{10}$ The area of each microscopic field was equal $0.173 \mathrm{~mm}^{2}$.

\section{Morphological analysis}

The morphology of 250 neurons of each studied group was analyzed, making use of membrane preparations, viewed on a microscope equipped with WF 10X ocular lens, micrometic disk attached, and a 40X system of lens. The purpose was measuring the major longitudinal and transversal axes of the cellular body as demonstrated in Figure 2 . 
Besides mensurations, the cytoplasm basophilic affinity, the nucleus position, the shape of the cells and the number of nucleoli present in each neuron were also observed. Neurons with uniform dark blue cytoplasm were classified as strongly basophilic. Neurons whose cytoplasm were showing multiple basophilic granules interpolated with areas slightly basophilic, were considered as neurons of intermediate basophilic affinity. The ones whose cytoplasm possessed few basophilic granules were classified as slightly basophilic neurons.

To classify the neurons as small, medium or large ${ }^{5.10}$, the mean and standard deviation of data resulting to the addition of the major longitudinal and transversal axes ${ }^{10}$ of 250 neurons of the proximal colon of animals from group $\mathrm{NN}$ were calculated. It was considered as medium neurons those whose addition of major longitudinal and transversal axes resulted in values fitted among those obtained when adding or subtracting the standard deviation to the mean. Neurons whose addition of major longitudinal and transversal axes resulted in values inferior to the mean subtracted of its standard deviation, were considered as small. As large neurons, it was considered those whose addition of major longitudinal and transversal axes resulted in values greater than the sum of the mean and the standard deviation ${ }^{10}$. The photographic documentation was performed with the aid of a WILD M20 photomicroscope.

\section{Statistical analysis}

The mean, standard deviation, and variation coefficient of the number of neurons found in each animal group, i.e., 200 fields per group, were calculated. The analysis of variance was applied to compare the difference among the means of the studied variable.

The Chi-square $\left(\chi^{2}\right)$ test was applied to analyze the significance of data referring to the frequency of small, medium and large neurons in the different groups of animals studied. The same test was applied for the results of the cytoplasm basophilic affinity.

The level of significance used for both tests was of $5 \%$.

\section{RESULTS}

\section{Morphology of neurons and myenteric ganglia: shape and localization}

The nervous ganglia of the myenteric plexus of the proximal colon were found more often among longitudinal and circular layers of the muscular tunica. Some of them could be found among the muscular fibers of the circular layer or immediately below the serosa layer where the longitudinal layer was not present. The ganglia were seen in different sizes and arrayed as a network (Fig 1).

It was observed that the ganglia were constituted by neurons of small, medium and large sizes (Figs 1, 2 and 3).

The small neurons usually presented central nucleus occupying the major part of the cellular body where it was observed only one nucleolus or just grumes in the nucleoplasm (Figs 2 and 3). Only two neurons showed nuclei with two nucleoli, which corresponds to $1.6 \%$ of the studied neurons.

In the medium size neurons as well as in the large ones, the nuclei were dense and spherical like, independent of the cellular body shape, which was determined by its cytoplasmatic content (Figs 2 and 3). Oval, circular and elongated cellular bodies were seen. The elongated ones differed from the ovals, for presenting a transversal axis smaller than the longitudinal in size, and for possessing sharp pointed borders. Regarding to the nucleus position, it could be named as polar when it was found in one of the extremities of the cell and enveloped by small quantity of cytoplasm that was concentrated in the nucleus opposite pole; peripheral, when the nucleus was seen in one of the cell's border with the cytoplasm equally distributed between its extremities; or, central, when the cytoplasm was found arrayed in a very regular manner, around the nucleus (Fig 2).

Most of the nuclei presented only one nucleolus. Among the medium neurons the duplicity was found in $7 \%$ of the nuclei. In the large neurons it was observed that $17 \%$ and $2.52 \%$ of the nuclei carried two or three nucleoli respectively.

\section{Frequency of the myenteric plexus neurons of the proximal colon}

Table 1 presents the frequency of neurons found in the animals of each studied group. For the data analysis of the means, analysis of variance was employed. Its results revealed no statistically significant difference among groups. 


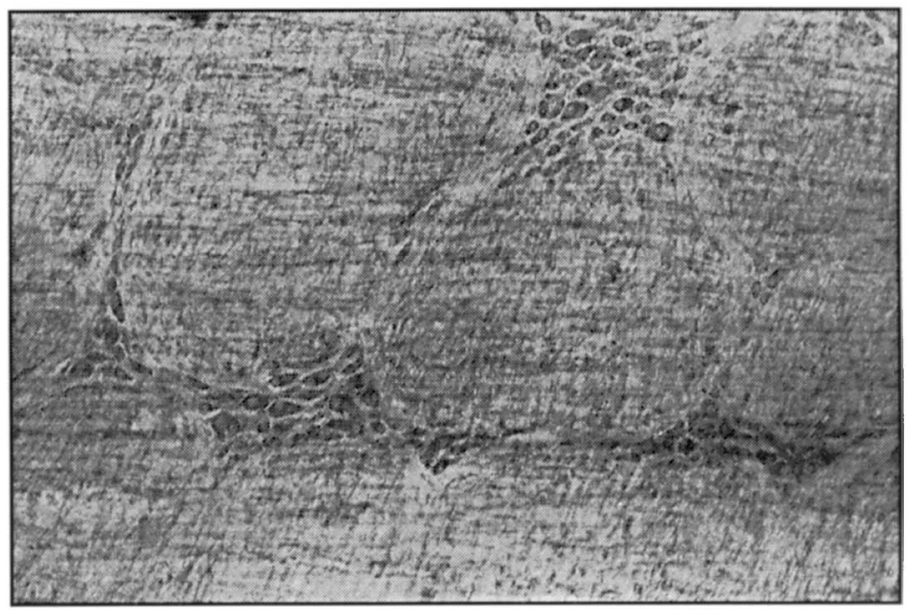

Fig 1. Membrane preparation stained by Giemsa's method displaying a group of nervous cells forming the ganglia of the myenteric plexus of the proximal colon.

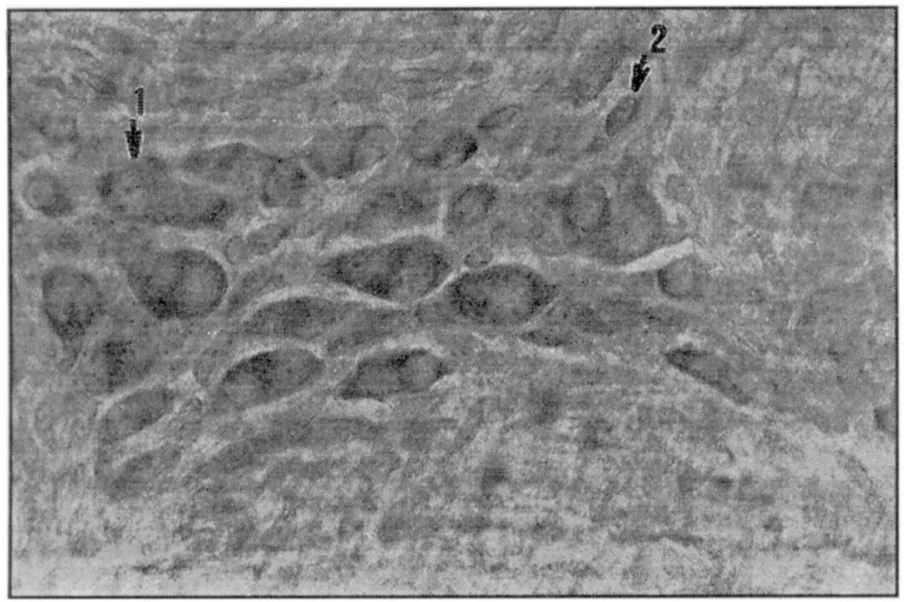

Fig 3. Membrane preparation stained by Giemsa's method displaying a myenteric plexus ganglion of an animal from Group DD. Notice: large neuron (1) and small neuron (2).

Morphometry of the myenteric plexus neurons of the proximal colon

Summing up the major longitudinal and transversal axes of the neurons, measurements varying from $13.10 \mu \mathrm{m}$ to $60.24 \mu \mathrm{m}$ were obtained. The small neurons were seen at $13.10 \mu \mathrm{m}$ and $18.33 \mu \mathrm{m}$ interval; the medium neurons were seen at $20.95 \mu \mathrm{m}$ and $34.05 \mu \mathrm{m}$ interval, and the large neurons at $36.66 \mu \mathrm{m}$ and $60.24 \mu \mathrm{m}$ interval. Table 2 shows the frequencies of the small, medium and large neurons found in the different studied groups.

Analyzing the frequencies reported on Table 2, no statistically significant difference was obtained applying the Chi-square test when comparing the four nutritional groups as a whole $\left(\chi^{2}=\right.$ 


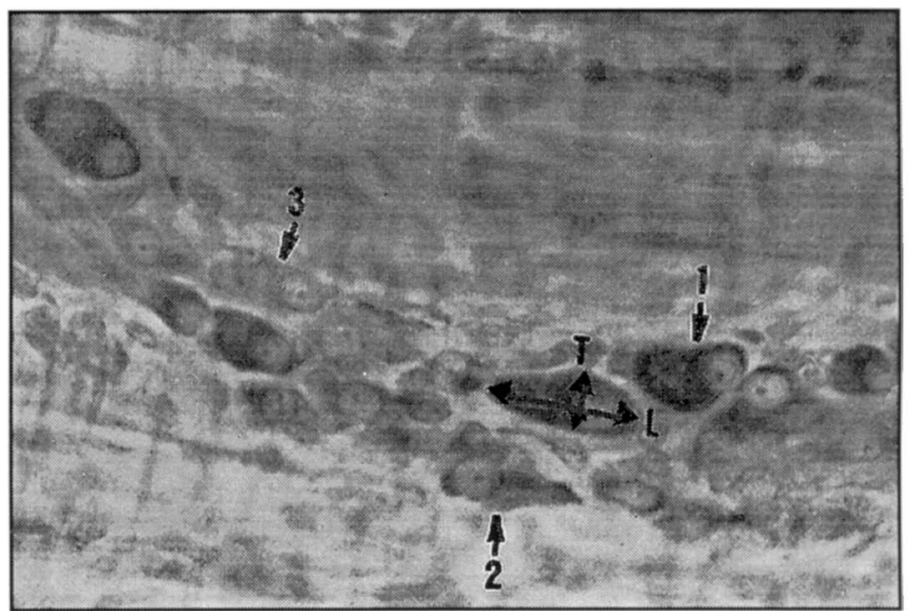

Fig 2. Membrane preparation stained by Giemsa's method displaying a myenteric plexus ganglion of an animal from group DN. Notice: strongly basophilic neurons (1), slightly basophilic (2), and of intermediate basophilic affinity (3). Lines L and $T$ indicate the major longitudinal and transverses axes.

Table 1. Frequency of myenteric plexus neurons found in a $0.173 \mathrm{~mm}^{2}$ area of membrane preparations of proximal colon of rats submitted to different nutritional treatment.

\begin{tabular}{ccccc}
\hline & \multicolumn{3}{c}{ Groups } \\
\cline { 2 - 5 } Animal & NN & DN & ND & DD \\
\hline 1 & 2639 & 2030 & 2605 & 2434 \\
2 & 2296 & 2368 & 1960 & 2388 \\
3 & 2229 & 1707 & 3009 & 2434 \\
4 & 2483 & 2896 & 2960 & 3086 \\
Mean & 1916 & 2260 & 1479 & 2589 \\
& 2312.6 & 2252.2 & 2402.6 & 2586.2 \\
\hline
\end{tabular}

NN, normal diet; DN, low protein diet during prenatal period, and normal diet durinf lactation period; ND, normal diet during prenatal period, and low protein during lactation period; $\mathrm{DD}$, low protein diet during prenatal and lactation periods.

10.75 for a critical value equal to 12.6 ). When comparing groups two by two, statistically significant differences were verified between group DD and other groups (Table 4).

Concerning affinity by staining, for large neurons the following results were obtained: $63.5 \%$ of them presented cytoplasm strongly stained, showing intense basophilic affinity; only 9.5 were slightly stained, while $25 \%$ showed intermediate staining. For the neurons of medium size, it was observed that $40.5 \%$ stained intensely; $18.9 \%$ slightly, and $40.6 \%$ showed intermediate staining. As for the small neurons, it was observed a proportion of $38.4 \%$ of strongly basophilic; $19.2 \%$ with low basophilic intensity, and $42.4 \%$ of the neurons were of intermediate basophilic affinity.

The basophilic aspects of the neurons found in each nutritional group is shown on Table 3. The comparative results obtained using the Chi-square test are demonstrated on Table 4 . 
Table 2. Frequency of small, medium and large neurons in the myenteric plexus of proximal colon of rats from different nutritional groups.

\begin{tabular}{ccccc}
\hline $\begin{array}{c}\text { Variable } \\
\text { Groups }\end{array}$ & $\begin{array}{c}\text { Small Neurons } \\
\text { (\%Lin.) }\end{array}$ & $\begin{array}{c}\text { Medium Neurons } \\
(\% \text { Lin.) }\end{array}$ & $\begin{array}{c}\text { Large Neurons } \\
(\% \text { Lin.) }\end{array}$ & $\begin{array}{c}\text { Total } \\
(\%)\end{array}$ \\
\hline NN & 37 & 182 & 31 & 250 \\
& $(14.80)$ & $(72.80)$ & $(12.40)$ & $(100)$ \\
DN & 27 & 188 & 35 & 250 \\
& $(10.80)$ & $(75.20)$ & $(14.00)$ & $(100)$ \\
ND & 31 & 180 & 39 & 250 \\
& $(12.40)$ & $(72.00)$ & $(15.60)$ & $(100)$ \\
DD & 30 & 166 & 54 & 250 \\
& $(12.00)$ & $(66.40)$ & $(21.60)$ & $(100)$ \\
\hline
\end{tabular}

NN, normal diet; $\mathrm{DN}$, low protein diet during prenatal period, and normal diet during lactation period; ND, normal diet during prenatal period, and low protein diet during lactation period; DD, low protein diet during prenatal and lactation periods.

Table 3. Frequency of myenteric neurons of proximal colon of rats from different nutritional groups according to different intensities of basophilic affinity shown.

\begin{tabular}{ccccc}
\hline $\begin{array}{c}\text { Basophilic } \\
\text { affinity/Groups }\end{array}$ & $\begin{array}{c}\text { Low } \\
\text { (\%Lin.) }\end{array}$ & $\begin{array}{c}\text { Intermediate } \\
(\% \text { Lin.) }\end{array}$ & $\begin{array}{c}\text { Strongly } \\
(\% \text { Lin.) }\end{array}$ & $\begin{array}{c}\text { Total } \\
(\%)\end{array}$ \\
\hline NN & 39 & 103 & 108 & 250 \\
& $(15.60)$ & $(41.20)$ & $(43.20)$ & $(100)$ \\
DN & 54 & 91 & 105 & 250 \\
& $((21.60)$ & $(36.40)$ & $(42.00)$ & $(100)$ \\
ND & 45 & 103 & 102 & 250 \\
& $(18.00)$ & $(41.20)$ & $(40.80)$ & $(100)$ \\
DD & 36 & 90 & 124 & 250 \\
& $(14.40)$ & $(36.00)$ & $(49.60)$ & $(100)$ \\
\hline
\end{tabular}

NN, normal diet; DN, low protein diet during prenatal period, and normal diet during lactation period; ND, normal diet during prenatal period, and low protein diet during lactation period; DD, low protein diet during prenatal and lactation periods.

Table 4. Values obtained by "Chi-square" $(\chi 2)$ test referring to the comparison of classes of neurons regarding size and basophilic affinity in the four animal groups studied.

Values of $\chi 2$ to frequency of neurons

Compared Groups Small, medium and large

Slightly, intermediate and strongly basophilic affinity

\begin{tabular}{lll}
\hline NN X DN & 4.60 & 3.99 \\
NN X ND & 3.01 & 1.92 \\
NN X DD & 9.14 & 4.50 \\
DN X ND & 1.61 & 4.09 \\
DN X DD & 7.74 & 6.67 \\
ND X DD & 6.15 & 4.60
\end{tabular}

$\mathrm{NN}$, normal diet; DN, low protein diet during prenatal period, and normal diet during lactation period; ND, normal diet during prenatal period, and low protein diet during lactation period; DD, low protein diet during prenatal and lactation periods. 


\section{DISCUSSION}

Our studies indicate that the maternal protein deprivation during prenatal or postnatal periods does not affect the arrangement nor the shape of the myenteric plexus ganglia considering that in the four groups of animals studied, the mentioned ganglia were found among muscular layers, agreeing with the description of several authors ${ }^{6,10-14}$.

As mentioned in our results, in the enteric neurons there is a predominance of cells with their nuclei positioned in the periphery of the cellular body. Thus, the nucleus peripheral position does not constitute an indication of a degenerative process as it happens with the central nervous system neurons which possess central nucleus that dislocates itself to the periphery when the cell starts to degenerate ${ }^{6,12}$.

In our study it was observed that $63.5 \%$ of the large neurons possessed strongly basophilic cytoplasms. Other authors found strongly basophilic cytoplasms in $77.3 \%$ of the large neurons of the ileum ${ }^{10}$ and in $100 \%$ of the large neurons of the duodenum ${ }^{14}$. Strongly basophilic cytoplasms were also found in $40.5 \%$ of the medium neurons and in $38.4 \%$ of the small neurons. Weakly basophilic cytoplasms were found in $9.5 \%$ of the large neurons, in $18.9 \%$ of the medium neurons, and in $19.2 \%$ of the small ones. This clearly indicates that among large neurons predominates cytoplasms of intense basophilic affinity. It was also observed that among the large neurons the nuclei with multiplicity of nucleoli are in great number, as it is mentioned by several authors ${ }^{10,14}$. The multiplicity of nucleoli is the indication of higher rate of protein synthesis, which is confirmed by the intense cytoplasm basophilic affinity. It is known that neurons with greater synthesis activity possess greater quantity of granular endoplasmatic mesh and free polyribossomes ${ }^{6,12}$. These structures due to their affinity by basic staining, are responsible for the cytoplasm staining. When in great quantity, they result in intensely stained cytoplasm, and when in smaller proportion, the cytoplasm gets slightly stained ${ }^{6,12}$.

Although the animals from groups ND and DD had presented measurements numerically superior than groups NN and DN, no statistically significant difference was revealed among the means of neuron's quantity in the four studied groups. In a previous research carried out with animals submitted to the same conditions, the number of neurons in the duodenum of the animals from groups ND and DD was significantly greater than in the animals from groups NN and $\mathrm{DN}^{14}$. In the likeness of these authors, we presumed that the greater number of neurons is due to a lower growth rate of the animals from groups ND and DD. The animals from groups NN and DN had a better development reaching greater augmentation of their intestines, consequently, contributing to a lower neuron density per area. Therefore, the results indicate that the malnutrition in the studied periods does not provoke reduction on the number of myenteric plexus neurons of the proximal colon.

It was found that in group DD, the frequency of large neurons was greater than in the other groups. However, more significant values were found in the duodenum of animals submitted to the same treatment ${ }^{14}$, where $88 \%$ of the neurons were large. The referred authors relate the greater frequency of large neurons to a possible compensatory mechanism that might lead undernourished animals to store protein in the cell's cytoplasm when resuming normonourishment. The results obtained are in agreement with this proposition, adding to that the fact that the animals from group DD showed greater percentage of neurons with strongly basophilic cytoplasm. The fact that the animals from group DN presented no differences when compared to group NN suggests that malnutrition during gestation period does not affect the cells morphology of the pups myenteric plexus. This proposition agrees with histochemical studies which showed no alteration in the enzymatic activity of the myenteric neurons of rats whose mothers were submitted to a protein deprivation during prenatal period ${ }^{16}$. These data, however, are opposed to other observations carried out on rats ${ }^{18}$, humans ${ }^{19}$ and guinea pigs ${ }^{3}$ when reduction in number and size of the central nervous system neurons after pre and postnatal malnutrition was found. 


\section{CONCLUSION}

The results described in this paper when compared to reports of Natali ${ }^{13}$ indicate that the effects of protein deprivation during prenatal and lactation periods cause less intense alterations on the myenteric neurons of the proximal colon than as verified on the myenteric plexus of the duodenum of animals submitted to identical treatment. It was possible to conclude that the undernutrition in the mentioned periods does not alter the frequency of neurons per area of the myenteric plexus of the proximal colon. It was also found, that in the animals of group DD there was a storage of protein in the cytoplasm of the myenteric plexus neurons, increasing the quantity of large and strongly basophilic neurons.

\section{REFERENCES}

1. Barbosa AJA. Técnica histol6gica para gânglios nervosos intramurais em preparados espessos. Rev Bras Pesq Méd Biol 1978;11:95.97.

2. Brookes SJH, Costa M. Identification of enteric motor neurones which innervate the circular muscle of the guinea-pig small time. Neurosci Letters 1990;118: 227-230.

3. Chase HP, Dabiere CS, Welch NN, O'Brien D. Intra-uterine undernutrition and brain development. Pediatrics 1971;3:491-500.

4. Conboy VB, Santer RM, Swift GL. Effects of prenatal undernutrition on prevertebral sympathetic neurons in the rat: a morphological and fluorescente study. J Anat 1987;154: 47-53.

5. Cook DR, Burnstock G. The ultrastructure of Auerbach's plexus in the guinea-pig: 1. Neuronal elements. J Neurocytol 1976;5:171-194.

6. Cormack DH. Ham Histologia. Ed 9. Rio de Janeiro; Guanabara Koogan, 1995: 273-287;384-404.

7. Firmansyah A, Suwandito L, Penn D, Lebenthal E. Biochemical and morphological changes in the digestive tract of rats after prenatal and posnatal malnutrition. Am J Clin Nutr 1989;50:261-268.

8. Furness JB, Costa M. The enteric nervous system. Edinburg: Churchill Livingstone 1987:27-33.

9. Gabella G. Innervation of the gastrointestinal tract. Int Rev Cytol 1379;59:129-193.

10. Hernandes L. Estudo morfológico da mucosa e do corpo celular dos neurônios do plexo mientérico do neo de ratos com diabetes mellitus induzido por estreptozootocina. Dissertaçāo (Mestrado), Universidade Estadual de Maringă. Maringá, 1994.

11. Irwin DA. The anatomy of Auerbach's plexus. Am J Anat 1931;49:141-166.

12. Junqueira LCU, Carneiro J. Histologia básica. Ed. 8. Rio de Janeiro: Guanabara Koogan, 1995:245-267.

13. Matsuo H. A contribuition on the anatomy of Auerbach's plexus. Jpn J Med Sci Anat 1934;4:417-428.

14. Natali MRM. Efeitos da desnutriçăo proteica materna sobre a morfologia da mucosa e de neurônios do plexo mientérico do duodeno de ratos. Dissertação (Mestrado), Universidade Estađual de Maringá. Maringá, 1993

15. Santer RM, Conboy VB. Prenatal undernutrition permanently decreases enteric neuron number and sympathetic innervation of Auerbach's plexus in the rat. J Anat 1990;168:57-62.

16. Shrader RE, Zeman FJ. Effect of maternal protein deprivation on morphological and enzymatic development of neonatal rat tissue. J Nutr 1969;99:401-421.

17. Sternini C. Structural and chemical organization of the myenteric plexus. Ann Rev Physiol 1988;50:81-93.

18. Winick $M$, Noble A. Cellular response in rats during malnutrition at various ages. J Nutrition 1966;89:300-306.

19. Winick M, Rosso P. The effect of severe early malnutrition on cellular growth of human brain. Pediatrics Res 1969;3:181-184. 